\title{
SMAD1 wt Allele
}

National Cancer Institute

\section{Source}

National Cancer Institute. SMAD1 wt Allele. NCI Thesaurus. Code C106612.

Human SMAD1 wild-type allele is located in the vicinity of $4 q 31.21$ and is approximately $78 \mathrm{~kb}$ in length. This allele, which encodes mothers against decapentaplegic homolog 1 protein, is involved in the regulation of cell growth, apoptosis, morphogenesis, development and immune responses. 